\title{
0 que move a história? - Voltaire, Bodin e 0 interesse pelas revoluções
}

D ouglas Ferreira Barros

douglasfbarros@gmail.com

Pontifícia Universidade Católica de Campinas, Campinas, São Paulo, Brasil

resumo 0 presente texto visa avaliar 0 estatuto da revolução a partir da obra de dois filósofos franceses, por assim dizer, que empenharam parte considerável de seu trabalho na investigação sobre a história: Voltaire e J ean Bodin. Nossa intenção é entender a relação entre as noções de transformações, revolução e guerra, conflitos, tumultos. Não pretendemos estabelecer uma comparação rígida, porque anacrônica, entre as obras desses filósofos que trabalharam sobre a história. 0 que intentamos aqui é investigar algumas linhas de força de seus argumentos que visam explicar as revoluções, suas origens e consequências para mostrar como a articulação entre esses elementos possibilita a Voltaire e a Bodin que realizem o que chamaremos de desmistificação de aspectos pertinentes tanto à filosofia quanto à história. Trata-se ainda de mostra em que medida Bodin e Voltaire divergem e se encontram no que tange ao tratamento filosófico desses temas.

palavras-chave História; Revoluções; Política; Ilustração; Voltaire; J ean Bodin.

0 objetivo do presente texto é investigar as revoluções, segundo a abordagem das histórias estabelecida por dois franceses que para muitos não são dignos de figurar no Panteão dos grandes filósofos: Voltaire e Jean Bodin. Trata-se de tema que, para autores como D escartes, por exemplo, de modo algum constituiria objeto para 0 interesse filosófico. ${ }^{1} \mathrm{D}$ istanciando-nos dessa perspectiva, nosso intento aqui é avaliar o queVoltaire e Bodin entendem por revoluções, que fatores podem desencadeá las, quais consequências acarretam. Também, nos interessa investigar como, pelo estudo da história, se podem notar vestígios desses fatores que dariam

R ecebido em 22 de maio de 2011. A ceito em 19 de julho de 2011.

doispontos, Curitiba, São Carlos, vol. 8, n. 1, p.37-62, abril, 2011 
início às transformações, às mudanças, à irrupção da contingência na regularidade sucessiva dos acontecimentos. N ossa hipótese de investigação é que, ao explorarem a noção de revolução e a confrontarem com certa compreensão da história, os pensadores intencionam realizar um tipo específico de desmistificação que mira certos topói quase incontestáveis de uma certa compreensão sobre a história e de uma interpretação de aspectos da filosofia a partir da história.

\section{Método e desmistificação}

D ois fatores esclarecem nossa opção por trabal harmos estes, segundo seus críticos, "filósofos pouco filosóficos", que escreveram sobre as revoluções na história, antes da R evolução Francesa. Primeiro, trata- se neste caso de pensadores que se empenharam para estabelecer um conhecimento daquele campo do saber humano que se presta às críticas mais severas por parte dos que, como D escartes, falam em nome das ciências e da verdade. A mbos conservam o estudo e a interpretação da história como um dos pilares centrais de sua investigação teórica e não se furtam ao desafio de extrair dela um conhecimento cuja relevância e utilidade aspira ir além da compreensão do encadeamento ou não de circunstâncias temporais específicas. Em segundo lugar, observando algumas das singularidades de seus escritos sobre a história, veremos que os dois filósofos se esforçam para manter em diálogo os temas desse domínio do saber e temas clássicos da filosofia.

A discussão acerca do método, para citar um desses temas, diz respeito diretamente a alguns de seus trabalhos mais importantes. No caso de Bodin, a especulação sobre a mais perfeita das repúblicas ocupará o centro de seu interesse justamente na obra dedicada à exposição do método fácil para o conhecimento das histórias, ${ }^{2}$ o M ethodus ad fadilem historiarum cognitionem (1566). Justamente aí, entre outros assuntos, ele se pergunta pelas causas das revoluções, circunscrevendo sua análise às transformações das repúblicas na história.

Ao investigar o mesmo tema,Voltaire destacará os benefícios para a humanidade e a civilização que se encontram nos períodos históricos mais significativos desde a antiguidade, as razões que explicam o declínio 
do grande século de Luís XIV, e os nomes históricos, personagens, que exerceram influência decisiva nesses momentos. Ele o fará, segundo os críticos, alheio às exigências métódicas de exposição e investigação. M as, segundo os admiradores deste filósofo, a preocupação com um método específico está ali pressuposta.

É fato que os textos de Voltaire que em momentos se ocupam das revoluções, como o Essai sur les moeurs et l'esprit des nations (1756) e o D icionário Filosófico (1765), trazem suas observações sobre esse tema de forma pouco sistemática, dispersas. N ão se encontram neles pistas claras sobre a orientação metódica assumida que possa conduzir o leitor desde um ponto de partida preciso até outro marco que indique o termo da investigação. 0 s trechos dedicados à revolução seriam então meras observações sem importância, ou teríamos ali de fato uma reflexão sobre as revoluções que acarretasse consequências para a compreensão de outros elementos de suas obras?

O ra, que Voltaire não tenha desenvolvido de modo sistemático suas teses so bre os temas da filosofia e de outros domínios do saber é assunto que admiradores e críticos de sua obra se dedicaram a discutir. Isso não nos autoriza a pensar, contudo, que nos textos voltairianos não encontremos uma ordem produtora de sentido. D efende Pomeau (PO M EAU, 1957, p.09-10) que o modo voltairiano de pensar a história e de historiar não é desordenado e que ele se orienta por um método específico. C laro está que esse pensamento tipicamente setecentista não se estrutura em função de método que se apresentaria como seu fiador absoluto, como garantia infalível de que o filósofo conduz seus raciocínios ou a investigação à verdade, à maneira do racionalismo de matriz cartesiana. 0 que não implica que a reflexão voltairiana seja desprovida de método. A final, o texto em que nos reporta os motivos da decadência do grande século francês (o de Luís XIV), por exemplo, é inegavelmente dotado de "clareza, precisão, reflexões curtas e plenas de sentido". Esses alvos, defende Pomeau, não se atingem sem o uso preciso de um método.

U m dos aspectos que explicitaria a intenção do trabalho metódico do Voltaire historiador está no tom crítico constante nos seus mais diversos textos desse gênero. C omo crítica se pode entender a insistência do filósofo em revisitar certos lugares comuns, eleitos por historiadores reconhecidos como clássicos, dando-Ihes nova interpretação. 
Também, a compreensão voltairiana se impõe como crítica porque propõe a revalorização daquilo que foi digno de admiração e nos é apresentado por inúmeros historiadores como lições de um passado a ser imitadas no presente.

Pomeau observa com relação a esse aspecto do texto voltairiano a aplicação, em outra chave, de um elemento valioso das regras cartesianas. "N ão tomar como verdadeiro nada que suscite a menor dúvida" é o que D escartes defende para que, após encontrar um ponto fixo e seguro, possa erguer sobre uma evidência o edifício do conhecimento. Já a verve cética deVoltaire nos adverte a não tomar nenhum relato como verdadeiro e dele extrair conclusões definitivas antes que o mesmo seja cotejado com os fatos e dessa confrontação se possa distinguir o que é história e o que são fabulações de historiador. Porque, afirma Pomeau, com termos selecionados nos textos do próprio Voltaire,

Em primeiro lugar, [a história procura] evitar 'a precipitação e a prevenção'. [...] 'N ão pôr jamais sua imaginação no lugar das realidades', isto é, resistir à atividade naturalmente fabuladora do espírito humano. Enfim, 'despojar de todo espírito de partido', e 'não ser de nenhum país' (PO M EAU, 1957, p.13).

0 que significa evitar a precipitação? Tomar o trabalho do historiador como um dado do real, como a transcrição fiel dos acontecimentos. Por que e a que se deveria resistir? Exatamente preservar-se da intenção dos historiadores de apresentar a verdade como inerente à coerência de seu discurso. R esistir paraVoltaire é não aceitar o espírito de defesa assumido por certos historiadores sobre a sua própria experiência, sobre o seu povo, sobre os seus governantes e as suas leis. Por que tantas vidas, tantos povos, tantas batalhas, exércitos e generais seriam dignos de louvor? Admitir, como fazVoltaire, como elemento constitutivo de sua crítica que é preciso "não ser de nenhum país", não ter o "espírito de partido", põe em relevo a postura de desconfiança sobre as criações dos historiadores. Ele avalia claramente como suspeita a natureza fabuladora do espírito humano. Q ue resultados tais criações produziram? Com a pretensão de nos revelar o verdadeiro da história elas terminariam produzindo mistificações, a saber, posicionando a "imaginação no lugar das realidades". 
R esta então saber 0 que da história nos permitiria acusar tais tendências de mistificação. É o tema das revoluções que nos conduz à observação clara de como o posicionamento crítico se apresenta como método e por que merecem desconfiança os historiadores e suas histórias. Tanto paraVoltaire quanto para Bodin, as revoluções nos possibilitarão confrontar uma intenção, comum a tantos historiadores, de atribuir um sentido unívoco ao conhecimento da experiência de vários povos, de várias batal has, inúmeros governos e governantes, incontáveis poderes e derrotas. 0 que nos causa surpresa é que, em se tratando de pensadores cujas obras se distanciam no tempo por quase dois séculos, e, como se verá, em posse de diferentes acepções e usos do método de leitura e compreensão da história, ambos elejam o tema das revoluções como tópos insubstituível da investigação.

No caso de Bodin, a proposta de um método de conhecimento da história não põe ênfase apenas sobre o posicionamento crítico, que visa à desmistificação dos lugares comuns preferidos dos escritos dos historiadores, embora isto também esteja em seu projeto. $0 \mathrm{M}$ ethodus pretende aprimorar as concepções clássicas, que remontam a Cícero e A ristóteles, segundo as quais o método designa ratio ou via, muito próximo do significado grego de techné, atingindo um sentido equivalente latino com a noção de ars (Cf. C O U ZIN ET, 1996, p.19). Partindo da concepção de que, no contexto amplo das artes $\mathrm{H}$ istoricae, tal gênero de saber é constituído pelas artes da escrita e as artes da memória, amparadas nos elementos da retórica clássica, Bodin intenta introduzi-lo ao método.

Como um instrumento que facilita e proporciona o conhecimento, 0 método é o que permitirá ao pensador sistematizar a história segundo critérios de conhecimento já estabelecidos por outras disciplinas melhor estruturadas segundo critérios rigorosos - cosmologia, direito, geografia. Entre esses critérios está a necessidade de reclassificar os lugares comuns da história e apresentá los segundo uma ordem de fácil compreensão, de modo a tornar acessivel o trabalho de julgamento a ser feito pelo leitor da história. E o que este julgará? Ele poderá julgar que povos, governos, repúblicas foram bem sucedidas na tarefa de garantir a boa vida dos cidadãos que as constituíam. Exatamente neste trabalho de julgamento da história como um saber portador de uma veracidade acerca da experiência humana e não de uma verdade sobre a mesma é que seremos apre- 


\section{2}

sentados por Bodin ao que de melhor fizeram os governos e as repúblicas para se proteger das turbulências políticas e à razão pela qual inúmeros dentre eles foram dissolvidos pelas revoluções.

Ao enfocarem o tema das revoluções, a nosso ver, Voltaire e Bodin assumem um trabalho reflexivo que ultrapassa a discussão sobre detalhes históricos ou sobre o caráter abrangente, unívoco e que aspira à verdade da experiência humana contido na própria história. Eles a tomam como um pretexto para propor uma reflexão filosófica acerca dos limites da nossa compreensão sobre o passado. A intenção que atravessa as análises de ambos é, em última instância, a de fazer a crítica, ou, como dissemos, desmistificar este saber que pretende, se não impor-se como verdade, pelo menos impor verdades aos que dele se valem. E ao fazerem isso, ambos terminarão por afirmar a legitimidade de seu julgamento sobre a história, em face daqueles que antes deles se apresentaram como portadores da verdade histórica.

\section{Revolução, afinal, o que é, qual sua importância e que consequências produz?}

C omeçando porVoltaire, o que encontramos em suas exposições sobre 0 tema das revoluções é a mesma dispersão expositiva a ser notada na apresentação de inúmeros temas considerados centrais em seus textos: a crítica aos filósofos, a suspeita acerca dos trabalhos dos historiadores, entre outros. O s relatos não nos conduzem a uma definição precisa do tema, embora o mesmo figure em partes tão importantes de al gumas obras que dificilmente passaria incógnito mesmo pelo leitor mais desatento.Veja-se, por exemplo, a introdução ao E ssai sur les M oeurs et I'E sprit des N ations (1756). N ela,Voltaire concentra seu interesse sobre o tema das mudanças que se deram no globo; como se provocasse os historiadores, ou o leitor das histórias, ou mesmo os filósofos, ele afirma que:

vocês desejariam que os filósofos tivessem escrito a história antiga, porque querem lê-la como filósofos. Procuram apenas verdades úteis, e nada encontraram, dizem vocês, além de erros inúteis. Tratemos de nos esclarecer conjuntamente; tentemos desencavar al guns monumentos preciosos sob as ruínas dos séculos (VO LTAIR E, 1990, p.03). 
$\mathrm{N}$ ão poderia ser mais explícita a intenção da referência ao caráter inovador - crítico? francamente cético? - da tentativa de revirar as ruínas dos séculos. "Tratemos de nos esclarecer conjuntamente", Voltaire adverte, levantando a suspeita de que os relatos de certos historiadores que aspiram à escrita ou à reflexão filosófica obscureceram nosso conhecimento sobre o passado. Também, ele desconfia dessa intromissão da filosofia, ou da pretensão filosófica dos leitores que se debruçam sobre os relatos: ela contribuiria para turvar nossa compreensão dos fatos. Por fim, e mais revelador das intenções céticas do texto, há uma constante a ser observada nesse percurso que oscila da busca pelo útil ao encontro com o erro: " pode ser que nosso mundo tenha sofrido tantas mudanças quanto os Estados tenham experimentado revoluções" (VO LTAIR E, 1990, p.03). Demonstrar que as revoluções são eventos mais constantes do que pensa e observa, como julgaVoltaire, a vã reflexão filosófica é justamente dar destaque ao elemento desmistificador, isto é, lançar dúvidas sobre aquilo que os historiadores elegeram como grandes eventos, períodos marcantes, personagens memoráveis, Estados fortes, indestrutíveis, insuperáveis, dignos de ser imitados. D esencavar "monumentos preciosos so b as ruínas" é justamente dar visibilidade ao que não ocupou o interesse e a admiração daqueles que se orientaram pelo que, de fato, dizem as histórias. Por que, então, as revoluções mereceriam ser desencavadas?

As revoluções dirão muito sobre o que foi o passado destes personagens e dos Estados a que pertenceram. Elas contam mais fielmente o que são os homens e que relações mantêm com os demais semelhantes: "Evitemos misturar o duvidoso ao certo e o quimérico com 0 verdadeiro. Temos bastantes provas das grandes revoluções do globo, sem procurar pelas novas" (VO LTAIR E, 1990, p.03). Q uais teriam sido essas grandes revoluções? Voltaire não estabelece distinção, muito menos hierarquia entre os eventos naturais e aqueles causados pelas mãos humanas - eventos artificiais, por assim dizer. C onstata apenas que acontecimentos de tanta magnitude 3 e importância se deram na mesma proporção lembremo-nos: "pode ser que nosso mundo tenha sofrido tantas mudanças quanto os Estados tenham experimentado revoluções" ? assim como se difundiram por todas as partes da terra. Pelo menos era esse ensinamento que poderíamos extrair da leitura, por exemplo, das Sagradas Escrituras. Ao se deter na investigação acerca da autoria do A pocalipse, 
Voltaire afirma:

A cada comunidade cristã foram imputadas as profecias contidas nesse livro. O s ingleses encontraram aí as revoluções da G rã B retanha; os luteranos, os tumultos da Alemanha; os reformados da França, o reinado de $C$ arlos IX e a regência de $C$ atarina de $M$ édicis: todas têm, igualmente, razão a esse respeito (VO LTAIR E, 1964, p.48).

O s sinais da importância desses eventos, talvez escondidos na atmoffera trágica e destruidora que os acompanha, denunciam a relação direta entre a disputa de interesses e a ocorrência dos mesmos. 0 que escondiam as letras soturnas do livro do A pocalipse não eram exatamente "profecias" imputadas "a cada comunidade cristã", mas sim o diagnóstico segundo o qual em todas as comunidades se poderiam encontrar a cobiça, o ódio, o orgulho, entre outras mazelas que deram origam às revoluções. 0 texto de São João explicitaria apenas que elas ocorrem de diferentes modos a tantos povos.

T ão decidido quanto Voltaire a desvelar a partir do conhecimento das histórias o caráter devastador das revoluções (conversiones in rerum publicarum), Jean B odin, no século X VI, já estabelece que suas ocorrências são comuns a todas as repúblicas e nunca seriam exclusivas de alguns povos. Pois, ao investigarmos a trajetória pela qual passam os ordenamentos humanos desde os menos complexos até aquelas repúblicas que triunfaram por longos anos veremos quão comuns são as transformações radicais por eles experimentados. Ele afirma: “... ao progredirmos, partindo primeiramente daquelas associações originárias, para que tudo esteja muito evidente a todos, descobriremos particularmente infinitas etapas e revoluções". (BO DIN , 1951, p.190b, L.54-58 (381b, L.10-17))4. N este caso, a investigação sobre certas características dos governantes nos informa mais sobre a origem e as causas das revoluções do que a leitura das Sagradas Escrituras. Bodin encontra os vestígios dos maus governantes com o estudo das histórias; também localiza aí os possíveis elementos desencadeadores das revoluções.

Em sua procura pelas causas desses eventos destruidores, Bodin revela que as revoluções têm origem em causas tanto externas quanto internas às repúblicas. É importante ressaltar que o que é externo para Bodin nesse tópico de sua investigação sobre a história no $M$ ethodus não nos remete a qualquer relação com a transcendência. A fragilização das insti- 
tuições públicas, devida aos conflitos entre os cidadãos e um tirano, por exemplo, tenderia a facilitar a invasão feita por uma república melhor constituída. Foi assim que, diga-se de passagem, R oma conseguiu, em diversos casos, expandir seus territórios. Fomentando a desunião dos cidadãos com os governantes dos locais que desejavam conquistar, os romanos criaram condições para obter o controle dessas mesmas regiões. N ote-se já na citação anterior que a dimensão política, por assim dizer, de tais eventos não nos é apresentada em paralelo com as transformações ocorridas na natureza - dimensão cósmica ou natural - , embora não seja absurdo estabelecer analogia entre elas. Isso nos serve como advertência contra qualquer dúvida quanto ao fato de que as revoluções sejam eventos gestados por ações humanas.

C abe aqui levantarmos a questão: essas transformações de que nos fala Bodin seriam já um indício de que os atos humanos podem ser pensados sem qualquer vinculação com as ordenações de D eus? 0 texto bodiniano não nos traz a resposta cabal a essa questão, mas o distanciamento entre os interesses e as ações humanos, as tranरfformações que engendram e qualquer tese sobre o poder de Deus sobre as criaturas denota que, pelo menos, um roteiro explicativo sobre a história e suas transformações não se explica exclusivamente pelas ordenações do Altíssimo.

O bserva-se em Voltaire uma operação semelhante pela qual a importância de considerações teológicas para explicação da história humana se reduz drasticamente. Voltaire, ao explicar-nos o termo "destino", em seu Dicionário Filosófico, defende que os filósofos persuademse de que todas as coisas são governadas por leis imutáveis, ordem na qual "tudo é um efeito necessário". Ele não exclui que as causas também estejam relacionadas aos interesses e às ações humanos, mas não deixa de estabelecer os estritos vínculos entre as leis da natureza, as leis do Ser supremo e os eventos terrestres.

O u o mundo subsiste por sua própria natureza, por suas leis físicas, ou um Ser supremo o formou segundo suas leis supremas: em um e em outro casos, essas leis são imutáveis; em um e em outro casos, tudo é necessário... Tudo é ordenado, encadeado e limitado... É contraditório que aquilo que foi ontem não possa tê-lo sido, que o que é hoje não possa sê-lo e é contraditório que o que deve ser não o seja (VO LTAIRE, 1964, p.162). 
$\mathrm{H}$ averia aqui alguma contrariedade entre as perspectivas de Bodin e de Voltaire? D e fato, o que encontramos é uma diferença de acento. Bodin, por concentrar a explicação das revoluções em sua investigação sobre as R epúblicas, detém sua atenção quase exclusivamente na história humana, embora não a desconecte definitivamente da divina e da natural.Voltaire, talvez por querer se apresentar como crítico da metafísica moderna, defende que a ordem necessária envolve a natureza e os eventos mundanos. $\mathrm{N}$ ão interessa fechar questão quanto ao fato de que a necessidade seja resultante da ordenação de D eus ou se as leis físicas a explicam. 0 juízo disjuntivo deixa em aberto as possibilidades: "O u o mundo subsiste por sua própria natureza, por suas leis físicas, ou um Ser supremo o formou segundo suas leis supremas". ParaVoltaire importa chamar a nossa atenção para o fato de que esta rigidez no ordenamento das leis sobre o mundo explica a ocorrência dos eventos, principalmente aqueles políticos. Q uem origina as leis ordenadoras? Pouco interessa, ou interessa menos do que a certeza de que elas governam todos os eventos. Ao mencionar as consequências da revolução inglesa, vemos quão insusbstituível é explicá-las segundo a ordem necessária que rege todos os acontecimentos “... se toda Inglaterra tivesse sido tragada pelo mar esse monarca não teria perecido sobre um cadafalso, ao lado de W hitehall. $M$ as as coisas estavam arranjadas de modo que $C$ arlos [I] deveria ter 0 pescoço cortado" (VO LTAIR E, 1964, p.162). 0 desfecho da história de Carlos I era necessário importando menos saber o princípio ordenador dessa necessidade: $D$ eus ou a natureza.

D aí se pode concluir quão surpeendente é a perspectiva deVoltaire ao afirmar a ocorrência das revoluções em diversos povos e que tal evento é tão comum quanto as reconfigurações dos poderes realizadas na sequência delas. 0 que responderiam os filósofos defensores da ordenação necessária de Deus para todo e qualquer ser criado? Como um evento poderia desafiar a ordem estabelecida pelo Ser supremo?

Imprevista que é, a revolução rompe com o que defendem os filósofos parceiros do racionalismo dogmático sobre a ordem necessária. A revolução é, pois, um desafio à própria persuasão, pelo menos na opinião deVoltaire, enganosa dos filósofos; um confronto à própria rigidez das leis ordenadoras dos eventos mundanos. M as, não estavam " as coi sas ... arranjadas de modo que C arlos [I] deveria ter o pescoço cortado" ? Sim e não. 
Q ue Carlos I seria morto, ninguém poderia duvidar. Todos morreremos: é da ordem da natureza. M as ninguém poderia saber previamente por que e por quem o $\mathrm{R}$ ei inglês seria morto. M enos ainda que esses eventos tenham se dado como resultante da ordenação divina. A certeza da ocorrência dos eventos tal vez dê razão ao racionalista metafísico, que crê ser a morte de Carlos I correspondente ao arranjo necessário em que estão dispostos todos os eventos: "é contraditório que o que deve ser não 0 seja". Todavia, o que desafia a própria metafísica clássica é justamente pensarmos que isto ocorre como resultante ou de forças da natureza, pelas leis físicas, ou pelas ordens de Deus. Seria possível, então, afirmar categoricamente queVoltaire trabalha, com a noção de revolução, como ruptura em relação aos pressupostos da metafísica moderna? Correto é admitirmos que ele desconsidera a importância de sustentar que tanto a irrupção das revoluções quanto outros eventos terrestres têm origem necessária e exclusivamente na ordem Divina.

Ainda que os filósofos creiam que a necessidade das leis da natureza seja reflexo da vontade do Ser criador, isso não nos autoriza concluir que os atos por Ele ordenados serão comprováveis historicamente. E com relação aos fatos históricos é mais importante que constatemos a necessidade de sua ocorrência do que concluir se a origem da ordem que os produz está na natureza ou no poder do Ser criador. 0 que terá impulsionado C romwell na Inglaterra, os reformados da A lemanha, os confederados na França, os grupos dissidentes em Florença a alterar o curso dos acontecimentos? H averia contradição no fato de Voltaire não cravar posição negando que a origem da necessidade é a ordem do Ser supremo? Como supúnhamos acima, a força de seu argumento reside muito mais no juízo disjuntivo acerca da origem dessa necessi dade. Seria inconsistente, então, concluirmos cabalmente que as revoluções se dão completamente desconectadas de uma ordem ou que elas tenham origem apenas em uma ordem - em D eus - em detrimento da outra - a natureza. $\mathrm{N}$ ada disso produz qualquer efeito para nossa compreensão da história.

A constatação das revoluções na história confronta propositalmente, mas não contradiz, a concepção defendida pela teologia e por certa tradição metafísica, segundo a qual a origem da necessidade presente no mundo está nas regulações, na vontade e na perfeição dos atos de Deus. As revoluções põem em destaque a menor importância de nos concen- 
trarmos na investigação da origem da necessidade - vimos acima: "vocês desejariam que os filósofos tivessem escrito a história antiga, porque querem lê-la como filósofos" (VO LTAIR E, 1990, p.03). N ão se afirma que as leis físicas sejam as da ordem D ivina, menos ainda que esta contradiga ou seja determinante daquelas. Além disso, parece-nos claro que tanto uma quanto a outra podem explicar a necessidade acerca do que ocorre. É necessário que as revoluções tenham ocorrido, que ocorram e que venham a ocorrer; assim como que tenha existido a ordem e todas as coisas sejam ainda reguladas. Sabe-se: "Tudo é ordenado, encadeado e limitado... É contraditório que aquilo que foi ontem não possa tê-lo sido, que o que é hoje não possa sê-lo e é contraditório que o que deve ser não venha a sê-lo" (VO LTAIR E, 1964, p.162). 0 que prevalece aqui é exatamente a intenção de desmistificar o status que envolve a origem da necessidade que governa os eventos do mundo, quando identificado exclusivamente à ordenação de D eus. Seria de menor importância o fato de que as leis físicas, ou as leis de D eus, ou a própria natureza ordenam os eventos da história. "O u o mundo subsiste por sua própria natureza, por suas leis físicas, ou um Ser supremo o formou segundo suas leis supremas: em um e em outro casos, essas leis são imutáveis; em um e em outro casos, tudo é necessário" (VO LTAIR E, 1964, p.162). D esmistificar aqui é rebaixar o nível de importância da exata constatação da causa explicativa da necessidade; é igualar em relevância as ordenações de D eus, das leis físicas ou da natureza do mundo, posto que para cada uma dessas causas o efeito é o mesmo. ${ }^{5}$ Interessante notarmos que essa desmistificação mantém relação com o mesmo destaque conferido por Bodin ao tema das revoluções.

\section{Revoluções e suas origens}

Q uando passamos ao texto bodiniano, a relação entre política e ordem cósmica se apresenta mais clara no sentido de nos mostrar como o autor desrespeita, ou não prioriza, por assim dizer, a compreensão da ordem estabelecida pelo Ser supremo. Talvez pelo fato de pensar segundo critérios renascentistas e não ter que se posicionar em relação ao racionalismo moderno, Bodin se permita valer de uma concepção menos 
fiel àquela que coloca Deus no início da cadeia geradora de todos os eventos históricos. N esse caso, é Políbio que nos ajudará a entender como a relação entre natureza e história não exige de nós a defesa intransigente da tradição metafísica cristã.

B odin sustenta que a origem das revoluções está diretamente associada à incapacidade humana de compartilhar tudo com todos. É o desejo de uns poucos homens de obter mais do que os demais, quando todos se encontram em uma mesma condição de vida e de organização social, que leva os primeiros a querer mandar e os segundos a não querer ser mandados pelos mais egoístas. Esta é a gênese dos primei ros desentendimentos públicos.

É certo que quanto mais toda associação e comunidade se diferencia daquela entre homem e mulher, mais elas enfraquecem. Pois quer a natureza que cada um queira mais que seja seu aquilo que deseja mais, e, exclusivamente seu, sem querer compartilhar com outros. A ssim, a natureza não tolera por muito tempo usos comuns das coisas (BO DIN . 0 p. at. p.191a, L.53-59 (382a, L.39-52)).

U ma vez que as relações amistosas forem substituídas pelas de competição por melhores posições, que a intenção de compartilhar for menor do que a de acumular, as condições para as discórdias entre os homens já estarão dadas, estejam eles dentro ou não das organizações públicas. Q uando uns dominam para conservar a sua condição de ter mais e querer conservar isso em detrimento dos demais, neste instante se instaura a desigualdade da dominação. É justamente aí que têm início 0 que Bodin identifica como as ações violentas. 0 que inspira os homens a gestar as revoluções? A necessidade de interromper o desequilíbrio na dominação desmedida estabelecida por poucos sobre os demais em uma ordem política, seja ela uma cidade, um povoado ou uma R epública.

...essa doce vida que os homens extraíram da associação mútua

começou a ser violada pelos desacordos, visto que os fracos,

evidentemente, eram oprimidos pelos poderosos, o queVarrão atribui à

natureza toda; quem pode mais, domina, como o peixe grande come os pequenos e o fal cão mata outras aves (BO D IN . 0 p. at. p.191b, L.14-22 (382b, L.20-26)). 
A instituição da soberania se justifica para interromper essa dominação desmesurada. Bodin sustenta que a instituição de um poder acima de todos aqueles que pretendem dominar para se proteger e àquilo que possuem é o que poderá dar freio à injustiça. $E$ quando a injustiça nasce dentro da própria soberania? N ão há saída senão que os injustiçados busquem destruir a soberania e possam instituir outra, que cumpra suas intenções de justiça. O u seja, para Bodin, as revoluções são ao menos explicáveis sem que tenhamos que recorrer à causalidade divina ou à Providência.

N o Dicionário Filosófico, Voltaire coloca a questão de modo similar quando nos explica que tipo de ações humanas enseja tranforormações. $\mathrm{N}$ em todos os tumultos, conflitos e guerras teriam por escopo as revoluções. 0 verbete desigualdade nos diz que "A miséria atada à nossa espécie subordina um homem a outro homem". U m componente menos vinculado à necessidade material e muito mais à condição de dominação do poder sofrida pelos homens é o que explica as ações revolucionárias. A desigualdade material seria, então, o elemento desencadeador das transformações? Sim, mas, dependendo de sua intensidade e magnitude, as revoluções não visariam dar fim a esse tipo de desigualdade. Pelo menos, é essa a primeira impressão que se tem ao lermos que a miséria leva à subordinação (C f. SO U ZA, 2001, 106-115). ${ }^{6}$ Além do que, a desigualdade não é um mal em si mesma (Cf. VO LTAIRE, 1964, p.171), o próprio Voltaire o diz, embora reconheça que a desigualdade mantém relação com a dependência. Então, que tipo de ações está na gênese das revoluções? Surpreende que nosso autor enfatize apenas que a dependência, a submissão, leva os homens à humilhação e à escravidão.

U ma família numerosa cultivou um bom pedaço de terra; duas pequenas famílias vizinhas têm campos ingratos e rebeldes: é preciso que as duas famílias pobres sirvam a família opulenta, ou que elas a degolem, o que pode acontecer facilmente. U ma das duas famílias indigentes vai oferecer seus braços para obter pão; a outra vai atacá-la e é vencida. A família serva é a origem dos domésticos e dos serviçais manuais, a família vencida é a origem dos escravos (VO LTAIR E, 1964, p.172).

Como dado constitutivo, e talvez indelével, da condição humana, a desigualdade material não é passível de ser corrigida em consonância 
com 0 interesse de uns poucos homens. A desigualdade está relacionada ao conflito e, portanto, à revolução apenas na medida em que dela provavelmente resultarão relações de dominação. São as mazelas do poder e da dominação sofridas pelos homens que os conduzem ao enfrentamento, aos conflitos, às guerras. "É impossível, em nosso globo maraviIhoso, que os homens vivendo em sociedade não sejam divididos em duas classes, uma de opressores, a outra de oprimidos, e essas duas se subdividem em mil, e essas mil têm ainda nuances diferentes" (VO LTAIR E, 1964, p.172), conclui nosso pensador em tom resignado. Por si mesma, a desigualdade não é um fator que incomode os homens tanto quanto a opressão. É apenas pelo fato de um homem estar ciente de sua condição de oprimido que ele se volta contra os opressores.

Todos os oprimidos não são absolutamente infelizes. A maior parte nasce neste estado e o trabalho contínuo os impede de sentir demasiadamente sua situação; mas, quando eles a sentem, se observam as guerras, como aquela do partido popular contra o partido do senado em R oma, aquela dos camponeses na A lemanha, na Inglaterra, na França (VO LTAIR E, 1964, p.172).

Embora constate que o povo é o desencadeador das insurgências, Voltaire não crê que ele possa extirpar a opressão. N osso pensador não tem ilusões quanto à força de resistência dos oprimidos. As guerras, ele afirma, sempre "terminam cedo ou tarde com a sujeição do povo, porque os potentes têm dinheiro e o dinheiro é mestre de todos em um Estado..." (VO LTAIR E, 1964, p.172). 0 ímpeto para vencer não corresponde em intensidade à intenção negativa da opressão. 0 problema reside em que de um lado se quer resistir à opressão e do outro as condições materiais favorecem essa dominação para os já beneficiados. $\mathrm{M}$ as, por que os pobres venceriam? Por que os nobres cederiam suas posições? C omo dissemos, Voltaire não tem ilusões quanto às ambições mais explícitas e intensas da natureza humana: "Todo homem nasce com um pendor bastante violento para a dominação" (VO LTAIR E, 1964, p.172). O s pobres não anseiam eliminar a desigualdade, mas tão somente ocupar o lugar dos seus opressores. A injustiça nesse caso, se for pensada segundo a posição dos opressores em relação aos camponeses, não reflete a situação de desigualdade material, embora isso também 


\section{2}

esteja implícito nesta discussão. Ela informa-nos so bre uma dada situação de dominação, insustentável no tempo.

Todo homem nasce com um pendor bastante violento para a dominação, a riqueza e os prazeres, e com muito gosto pela preguiça. Por consequência, todo homem gostaria de ter dinheiro e mulheres ou filhas dos outros, ser seu senhor, sujeitá- las a todos os seus caprichos e nada fazer, ou fazer apenas coisas agradáveis. Veja bem que com essas belas disposições é também impossível que os homens sejam iguais, que é impossível que dois pregadores ou dois professores de teologia não estejam enciumados um do outro (VO LTAIR E, 1964, p.172).

O que importa aVoltaire não é localizar a virtude nas ações de um dos lados especificamente, mas sim constatar que os tumultos sempre terão lugar entre os homens. Primeiro porque "a igualdade é, portanto, ao mesmo tempo a coisa mais natural e a mais quimérica" (VO LTAIR E,1964, p.172-3). Contraditório? N ão, se pensamos que 0 mais comum é que os indivíduos ao mesmo tempo contestem a desigualdade quando esta Ihes é desfavorável, mas desejam conservá-la ou nada fazem para alterar esta condição quando ela Ihes favorece. Por isso a igualdade é quimérica. U ma ilusão dos filósofos leitores de história? U topia de historiadores que desejam escrever como filósofos? $\mathrm{N}$ os dois casos 0 equívoco reside em tomar as fabulações como fatos dignos dos relatos de historiador. Além disso, a permanência da desigualdade indica que a dependência também é uma constante: sempre haverá dominação, embora o mais natural seja a igualdade. Também, "o gênero humano tal como é não pode subsistir", isto é, o fato de os homens se darem conta de sua condição submissa não significa que estarão condenados a resignar-se e aceitar essa posição como definitiva. Por que a dominação e a ignorância não são suficientes para amainar e eliminar as contendas? " $U$ m homem por sua própria vontade não deixará sua terra para vir trabalhar a de outro. E se você tem necessidade de um par de sapatos, não será um magistrado que irá fazê-lo para você" (VO LTAIRE, 1964, p.172-3). Então, que artifício eficaz poderia fazer com que um homem deixe de trabalhar para benecifiar a si mesmo e trabalhe para enriquecer outro? É pela dominação que os camponeses servem aos ricos; para desfazê-la, eles se indignam quanto à sua condição e se voltam contra os opressores; em 
benefício dessa dominação, os ricos se protegem dos camponeses; pelos tumultos criados de parte a parte se criam as revoluções.

Bodin também identificará certo tipo de dominação como o motor primeiro das revoluções. 0 tirano, ensinam-nos as histórias, é com mais frequência abatido pelos súditos. $A$ sua maior e única vontade é sujeitar os homens aos seus interesses mais pessoais (BO D IN , 1951, p. 192a, L.44- 46 - 382b, L.02-05). Se os desejos do tirano estão plenamente atendidos, por que razão as revoluções Ihe tiram o poder? O bserva Bodin que o que está em jogo na efetivação do poder nas repúblicas é a realização ou não da justiça. N ada justificaria a instituição da soberania se esta não servisse de anteparo à dominação opressiva de al guns homens sobre a maioria. A ssim, tanto mais uma república está sujeita a sofrer revoluções quanto menos a sua soberania realiza a justiça na dominação. Vale dizer que Bodin entende por república apenas a ordem política que resguarda em si um lugar específico para o exercício do poder supremo - lugar a ser ocupado por um, ou por vários ou por todo o povo. 0 mais injusto dos soberanos, por consequência a mais injusta das repúblicas, é justamente aquele para quem o poder é uma extensão de sua vontade pessoal. N estas observações evidencia- se o traço clássico do pensamento bodiniano. A existência do poder visa ao cumprimento da justiça, donde se conclui que a inexistência da justiça é a matriz das revoluções.

$\mathrm{N}$ as aristocracias, monarquias e democracias, indistintamente - pois, é tênue a diferença entre estas e oligarquia, tirania e anarquia - , é a injustiça na dominação que leva os homens a se insurgirem contra a soberania vigente. A tirania apresenta mai or vulnerabilidade, por mais estranho que isso nos possa parecer, porque a violência do poder recebe como reação, por parte dos súditos, o enfrentamento pela violência. Como vimos acima, nenhuma posição de poder é segura sempre, todas estão sujeitas às revoluções. Dado que a condição dos homens que aspiram ao poder é a de mover suas inteligências, astúcia e agilidade para se apossar e usufruir dele, Bodin, tanto quanto Voltaire, vê em todo ato de insurgência contra os opressores vigentes a intenção de reconfiguração dos limites da dominação. A intensidade dos tumultos é que poderá instaurar uma nova ordem para, digamos, a opressão. N o conflito de parte a parte com vistas à supremacia da dominação poderá residir, ou não, a força de disrupção das revoluções. 
Então, quando há alguém com intelecto elevado e com desejo de glória (pois os desejos de domínio não surgem em almas lânguidas, mas em mentes atentas e nas mais altas inteligências), de tal forma este alimenta a plebe com banquetes, distribuições e volúpia de espetáculos, [é] que obtém, sem nenhum mérito seu, honras e poder (BODIN, I bidem. p.193b, L.19-26 (385a, L.35-42).

Tão deplorável quanto o dos tiranos, o poder conquistado pelos demagogos não intenta realizar a justiça. Bodin enfatiza que nesses casos o que está em jogo é perversão do sentido último da soberania: a realização da justiça na dominação, preterida em benefício da imposição dos interesses de uns sobre as vontades de todo o povo. Q uando não agem para convencer a plebe de que são os portadores da justiça, os demagogos usam seu poder para convencê-la de que a melhor submissão é a que a faz render louvor aos tiranos. Seja utilizando a força, seja fazendo uso das palavras, dos belos discursos emitidos nos banquetes e espetáculos, tiranos e demagogos se completam na intenção de submeter sem limites os súditos.

...nada é mais deplorável do que a plebe, assistindo com prazer a grandes suplícios, louvar a equidade do tirano. $\mathrm{N}$ isto está o que é mais vergonhoso e abominável, porque dissimularam a má índole com aparência de religião e no templo dos deuses fingiram sem venerar. Assim, por outro lado, no mesmo local, foram vistos produzir em face uns dos outros o simulacro das virtudes (BO D IN , I bidem. p.194a, L.1518 (385b, L.44-47).

Como explicar por que, entre os antigos, A tenas se viu diante de tantas guerras e revoluções e Esparta se manteve segura por tanto tempo? Bodin está certo de que esta última, por suas instituições e pelos governantes, se manteve impermeável à sedução dos demagogos. Talvez esteja neste exemplo o símbolo maior causador das mazelas oriundas nas guerras. A tenas, por sua índole mais livre, não só teria abrigado como também teria dado proteção aos demagogos.

JáVoltaire, em L e Siècle de L ouis XIV, sustenta que, embora surjam de movimentos de contestação a tipos vários dominação desmedida, nem sempre as revoluções instauram a justiça. 
[C arlos I, R ei inglês] homem honesto, mas monarca mal aconselhado, se engaja em uma guerra civil que Ihe fez perder, enfim, como já dissemos, o trono e a vida, sobre um cadafalso, por uma revolução quase inaudita.

Essa guerra civil, iniciada na menoridade de Luis XIV, impede por um tempo a Inglaterra de participar dos interesses de seus vizinhos: ela perdeu sua consideração junto com sua felicidade. Seu comércio foi interrompido. As outras nações acreditaram tê-la enterrado sob suas ruínas, até o momento em que renasceu, rapidamente, mais formidável do que nunca, sob a dominação de C romwell, que a sujeitou portando o Evangelho em uma mão, a espada em outra, a máscara da religião sobre o rosto, e que, em seu governo, cobriu de qualidades de um grande rei todos os crimes de um usurpador (VO LTAIR E, 1957, p.625-26).

Voltaire não atribui qualquer nobreza ao ato revolucionário de Cromwell, como também não condena o fato de que o revolucionário inglês tenha estabelecido uma dominação cruel, empunhando a Bíblia e a espada. $\mathrm{N}$ ão se pretende aqui exaltar ou condenar de antemão os atose a biografia revolucionários, menos ainda estabelecer restrições ou louvações às decisões e ao modo de vida dos derrotados. Ele explora em primeiro lugar o modo pelo qual a emergência da revolução traz consigo a aspiração de restabelecimento da justiça na dominação; em segundo, o modo pelo qual o ato revolucionário não mantém por si mesmo qualquer compromisso com a justiça dessa mesma dominação: C romwell, em seu governo, "cobriu de qualidades de um grande rei todos os crimes de um usurpador".

R esta ainda saber quem são os homens que se insurgem contra a dominação desmedida. Seriam os revolucionários e as revoluções portadores de algum caráter moral especial?

\section{Conclusão: revolucionários, os mais comuns entre os homens?}

$\mathrm{N}$ a Introdução de L e Siéde de L ouis XIV ,Voltaire reconhece a importância de certos personagens históricos para a ocorrência das transfor- 
mações. Seriam eles especiais em relação os homens comuns? A o destacar a proeminência de certos nomes nos períodos de efetivo apogeu na história: Péricles e Alexandre, no século do maior progresso helênico; Augusto, no século de glórias dos romanos; os M édicis, no século que põe fim à Idade M édia; e Luiz XIV, no século de ouro de toda a humanidade, nosso filósofo claramente identifica nestes personagens os governantes que se destacaram em razão da grandiosidade dos feitos que promoveram. Sem nutrir ilusões quanto aos verdadeiros portadores da justiça, Voltaire reconhece que a paz ou a desordem dos estados, sua decadência ou sua glória dependem desses governantes, dos príncipes, pois é o governo que muda os costumes, que eleva ou faz decair as nações. C omo precisamente comenta Pomeau,

Voltaire vê na ação de tais personagens uma das forças motrizes da história. [...] Ele mesmo não se abandona, sem retorno, ao pessimismo antidemocrático que postula a doutrina. I dealista, "sensível" em seus momentos, ele não confunde o povo com "a canal ha". M esmo no pandemônio das superstições, reconhece nele alguns lampejos. Forças positivas trabalham para o bem da humanidade: "uma amor pela ordem anima em segredo o gênero humano". N ão é verdadeiro que o homem em sociedade aspira ao caos; os flibusteiros mesmos organizam sua anarquia. 0 homem, animal social, termina por colocar termo aos saques e destruições; a cada vez, sobre as ruínas das cidades mortas, ele trabalha para reconstruir uma sociedade habitável. 0 utra manifestação do instinto de vida: a engenhosidade mecânica, natural à raça humana, criou as ferramentas, que se transmitem através das revoluções da história. (VO LTAIR E, 1990, p.X LV-VI).

D iferentemente de R ousseau, 7 Voltaire sustentará que as artes são capazes de melhorar moralmente a humanidade. Convém notar que as virtudes transformadoras residem também no povo, embora, de fato, esses príncipes tenham trazido incontestáveis e inúmeros benefícios às sociedades. 0 povo teve seus momentos, menos frequentes do que os príncipes, os tais lampejos, de iluminação para fazer avançar a humanidade. As transformações por que passaram esses séculos e a influência que acarretaram aos seguintes parecem aqui dizer respeito também ao progresso moral; as revoluções remetem às transformações 
radicais do poder, ou à reconfiguração da injustiça da dominação de uns sobre os demais.

Para Voltaire, não obstante a história se transforme realizando um progresso, a teoria dos quatro séculos dignos de destaque, 8 distantes e distintos entre si, impõe dificuldades a quem sustenta a ideia de um desenvolvimento contínuo. Isso torna factível a emergência das revoluções como sinal desse movimento com vistas ao progresso. A queles homens que rompem a ordem necessária dos eventos podem ser tanto os príncipes quanto os mais comuns entre os homens do povo. Sustenta Voltaire, em L e siède de L ouis XIV, que "todos os tempos produziram heróis e políticos: todos os povos provaram revoluções; todas as histórias são quase iguais para quem pretende apenas pôr fatos em sua memória" (1957, p.616). Se, de um lado, alguns príncipes promoveram o aprimoramento moral e material nas quatro épocas que se destacaram na história da humanidade, as revoluções, de outro lado, não antecipam qualquer momento de redenção dos homens da exploração pelo poder político.

Entre os heróis e os políticos, todos aspiram ao poder. Se as quatro idades de apogeu da humanidade marcam períodos específicos em que se produziu o maior avanço moral e material em todos os tempos, elas são também entremeadas por eventos obscuros. "Cada época brilhante emerge isolada por falhas, cercada de trevas", destaca Pomeau. E conclui: ele [Voltaire] "pensa que a história se consuma com cataclismas sucessivos, comparáveis àqueles que balizam a história natural de Buffon: no curso de cada revolução, o velho morre, o novo nasce" (PO M EAU, 1990, pp.X LVIII-IX ). M omentos em que a humanidade avançou a patamares superiores de civilização há apenas quatro - sim, Voltaire sustenta que a civilização implica na elevação moral e material das sociedades. Já as revoluções são inúmeras e não necessariamente estão articuladas com a melhoria do padrão civilizatório. As revoluções reordenam os elementos constitutivos de uma sociedade. É o que afirma Jean Dagens acerca de R éflexions critiques sur la poésie et la peinture (1719):

...0 mundo está sujeito a mudanças e vicissitudes, cujos períodos não nos são conhecidos, mas cujas revoluções reposicionam sucessivamente a polidez e a barbárie, os talentos do espírito assim como a força do corpo e, consequentemente, o progresso das ciências e das artes, sua languidez e seu gradual desaparecimento, tal como a revolução do sol 
reordena as estações alternadamente. (DAGEN S, A pud PO M EAU, 1990, p.X LIX, nota 04).

Tampouco para Bodin, a insurgência contra os tiranos e demagogos seria um ato levado a cabo exclusivamente por homens de estatura moral elevada. As disputas e conflitos que ensejam as revoluções expõem, como vimos, o interesse pela alteração das posições de domínio, que implica a reinstauração da justiça pela condução da soberania segundo os interesses dos que a ela se submetem igualmente. $\mathrm{N}$ ão é porque intentam eliminar o tirano, extirpá lo do poder, que os revolucionários são portadores da verdade e da justiça, tampouco suas qualidades morais, por si mesmas, justificam a alteração das posições de domínio. É certo dizer que a tranforormação radical que engendram seja porta voz de uma demanda por justiça, mas nada pode garantir que a execução do poder efetivará tal demanda.

O s homens, por si mesmos, não são os emissários de uma boa nova de justiça, mas, tão somente, a ordem de sucessão do tempo responde à demanda por realização da justiça. Ao investigar a influência da historiografia grega sobre o pensamento de Bodin - Tucídides, em primeiro lugar ?, M arie-Dominique Couzinet avalia que a dissolução das soberanias corresponde a esse clamor pela instituição da justiça. Ela afirma: esses historiadores entendem que "o mundo sustenta sua organização a partir dajustiça e o tempo não é outra coisa que um processo de justiça" (1996, p.136). Para Bodin, a noção de justiça remete à ideia de ordem, e a irrupção revolucionária pode ser entendida como a iniciativa de instauração de uma nova ordem no tempo da política.

A aproximação entre os textos de Bodin e de Voltaire podem nos colocar em uma zona de risco interpretativa - entre o equívoco e a descoberta. $\mathrm{N}$ o entanto, avaliamos que esse trabalho produz bons resultados, principalmente ao colocarmos em destaque o tema da revolução. A leitura dos dois autores em paralelo nos permite compreender quanto procuraram levar ao limite o projeto de escrever sobre a história e pensála valendo-se para isso de elementos filosóficos. 0 intento de encontrar uma formulação, a mais universal possível, para representar as revoluções e sua relação com a história responde ao desejo de desconstruir, ou desmistificar os ícones edificados pelos historiadores equivocados, assim como a eles próprios e aos seus trabalhos. Justamente aqui podemos 
observar mais nitidamente essa influência da filosofia sobre a compreensão e o conhecimento da história.

Investigando aspectos atinentes às revoluções, Voltaire rebaixa a importância de atribuirmos a origem da ordem necessária dos eventos ou a D eus ou às leis da natureza; Bodin duvida da possibilidade de que uma república possa se edificar livre das contingências e do confronto com as mazelas humanas. N o primeiro caso, parece que os metafísicos clássicos e modernos, também os teólogos, encontram- se no centro da mira do filósofo iluminista; no segundo, é contra a tese platônica e agostiniana da república ideal que se apresentam os argumentos de Bodin. Em ambos os casos, a desmistificação significa desfazer certos consensos filosóficos e de uma leitura filosófica da história, que obscurecem nossa compreensão sobre o que, de fato, realizaram os homens e quais deles foram dignos de admiração em toda a história da humanidade. Ademais, se a investida desses dois filósofos sobre a história é ou não trabalho merecedor do título de filosófico, tal discussão é uma disputa a mais em aberto nesta, como afirma Lebrun, imensa "arte da guerra ideológica chamada 'filosofia'" (LEBRU N , 2001, p.11).

1 R eferimo-nos aqui à muito conhecida e fartamente comentada passagem das R egulae, segundo a qual "...nunca nos tornaremos $M$ atemáticos, por exemplo, embora nossa memória possua todas as demonstrações feitas por outros, se nosso espírito não for capaz de resolver toda espécie de problemas; não nos tornaríamos filósofos, por ter lido todos os raciocínios de Platão e A ristóteles, sem poder formular um juízo sólido sobre o que nos é proposto. A ssim, de fato, pareceríamos ter aprendido, não ciências, mas histórias" [itálicos nossos] (DESC ARTES, 2007, R egra III, p.12). D escartes procura estabelecer os critérios para uma caríssi ma separação entre o domínio da ciência, que se ocupa do conhecimento do que é verdadeiro, necessário e perene, e o domínio dos saberes contingentes, circunstanciais, particulares, pois são dependentes dos humores e da intenção daqueles que os realizam.

2 Cabe aqui destacar que o próprio Bodin utiliza o termo histórias por considerar esse domínio do saber não um todo uniforme e respeitar a divisão clássica que distingue a $\mathrm{H}$ istória em: história divina, natural e humana.

3 “A maior de todas essas revoluções seria a perda da terraA tlântida, se fosse verdade que essa parte do mundo tivesse existido. É verossímil que essa terra não era outra coisa senão a Ilha de $M$ adère, descoberta talvez pelos Fenícios, os mais ousados navegadores da antiguidade, esquecida em seguida, e enfim reencontrada no começo do século XV de nossa era" (VO LTAIR E, 1990, p.05). 
${ }^{4}$ Em todas as citações do texto de Bodin traremos a indicação das páginas, colunas e linhas. Entre parênteses citamos as informações da tradução francesa feita a partir do original em latim, indicado fora dos parênteses. Cf.: M ethodus ad facilem historiarum cognitionem (Paris, M artin le Jeune, 1566), ab ipso recognita, et multo quam ante loaupletior (1572), Édition et traduction de Pierre M esnard, In.: Jean Bodin, 0 euvres Philosophiques. Paris: 1951, p.104-269; 269-473.

$5 \mathrm{~N}$ ão é totalmente descabido estabelecermos aqui um paralelo entre a perspectiva voltairiana e o que faz M aquiavel no capítulo XXV d'O Prínape: "Q uantun Fortuna in rebus huma nis possit, et quomodo il li sit occurrendum". 0 pensador florentino afirma: "E'non mi è incognito como molti hanno avuto et hanno opinione che le cose del mondo sieno in modo governate dalla fortuna e da $\mathrm{Dio}$, che li uomini com la prudenza loro non possino correggerle, anzi non vi abbino remedio alcuno..." p.92. 0 que $\mathrm{M}$ aquiavel quis dizer ao afirmar que muitos têm a opinião de que as coisas do mundo são governadas pela Fortuna e por D eus? Se a Fortuna governa tanto quanto D eus, é preciso concluir que este não tem onipotência sobre as Suas criaturas. $N$ ão se nega aqui que D eus tenha poder e que este se exerça sobre todas as coisas. M as Ele não é o único poder. Se a deusa é ingovernável, então Deus é a força que ordena dentro de certos limites, menos a força da Fortuna. Enfim, que intenção haverá nesse paralelo entre as ações da Fortuna e as de D eus a não ser a de desmistificar a onipotência D este e conferir aos homens, seus interesses e suas ações o poder de resistir, tanto quanto possível, às ordenações desgovernadas da deusa? 0 que poderia desafiar mais as opiniões doutas e comuns, em pleno século XVI, do que comparar a força de D eus com a de uma mulher? A lém disso, M aquiavel conclui dizendo que o poderá impor alguma resistência à deusa é a V irtù.

${ }^{6}$ Tanto paraVoltaire quanto para Bodin as revoluções constituem-se de embates que destroem as estruturas sobre as quais se assentam os governos, as cidades, as repúblicas. N enhum sinal elas emitem sobre a reconstrução de novas formas de governo ou de estados. M enos ainda, de uma dada revolução se poderá inferir que arranjo político será gestado das ruínas do anterior. A ssim, igualmente entre os ingleses, os franceses e os florentinos, as revoluções nos informam muito sobre o grau presente e passado de degradação, das relações entre os cidadãos e os governantes, que comportavam estas repúblicas. A regularidade das transformações entre as formas: monarquia, tirania, aristocracia, oligarquia, democracia e anarquia, não contempla imprevisões no curso da geração e da dissolução das repúblicas. Esse detalhe, portanto, que é a regularidade na transformação, nos auxilia para que tenhamos mais claro que tipo de mudanças engendram as revoluções se comparadas à dissolução das formas de governo polibiana. De fato, este não é apenas um detalhe, mas o ponto a partir do qual tumultos, conflitos, embates e guerras podem ser qualificados como revoluções. No caso deVoltaire, é necessário que ocorram as revoluções, porém não é por quaisquer causas que elas se geram. M as, uma vez que estas estejam dadas, nada poderá deter sua ocorrência.

Para que entendamos, na concepção bodiniana, a intensidade destrutiva que comporta as revoluções é importante determos nossa atenção sobre a clara a influência da teoria das metabolai ton politeion - a transformação das formas constitucionais - de Políbio. Bodin ampara sua compreensão sobre as revoluções em consonância com uma ordem natural - que é reflexo do desejo humano por justiça na dominação. As transformações que se dão nas repúblicas constatadas por Políbio nos levam a pensar justamente a intensidade das mudanças que estão envolvidas nas revoluções. U m detalhe, entretanto, distancia essas concepções de Bodin e 
Políbio: "... esta teoria [polibiana] das transformações naturais (katà physin metabolês) em cada uma das diferentes formas de governo..." (PO LíBIO, 2003, p. 277) não se refere especificamente às revoluções, tal como lemos no texto do pensador francês. Ela põe em primeiro plano a instabilidade como constitutiva de qual quer instituição política assim como do poder, em sentido amplo. As revoluções, na concepção bodiniana, dissemos, implicam em mudanças de outra intensidade.

${ }^{7}$ Cf. RO U SSEAU, 1978.

${ }^{8} \mathrm{Ao}$ escrever sobre a história dos" quatro grandes séculos", em 0 Séalo de L uís XIV (Le siède de Louis XIV ), Voltaire os considerou momentos em que "espírito humano mais se aperfeiçoou". 0 que produziu tal aperfeiçoamento? 0 s governantes que souberam conduzir 0 povo e tornaram factível o florescimento dos grandes feitos. Ele afirma: "C es quatre âges heureux sont ceux où les arts ont été perfectionnés, et qui, servant d'époque à la grandeur de l'esprit humain, sont l'exemple de la postérité (p.617)." Entendendo por século o período, ou a época, marcado pelo comando dos governantes, Voltaire os divide assim: primeiro: 0 de Felipe e Alexandre, que determina a Grécia clássica; 0 segundo: 0 de César e Augusto, entre os romanos; terceiro: 0 dos M édici na Itália do R enascimento; e o quarto: 0 de Luís XIV na França. (Cf.VO LTAIR E, 1957, I).

${ }^{9}$ Cf. CONSO LIN , 2002, p.162-4

\section{Referências Bibliográficas}

BO DIN , J. M ethodus ad fadilem historiarum cognitionem (Paris, M artin le Jeune, 1566), ab ipso recognita, et multo quam ante locupletior (1572), Édition et traduction de Pierre M esnard, In.: Jean Bodin, 0 euvres Philosophiques. Paris: 1951, p.104-269; 269-473.

DESCARTES, R . 2007. R egras para a orientação do E spírito. São Paulo: $M$ artins Fontes.

CASSIR ER , E. 1997. A filosofia do Iluminismo. São Paulo: Paz eTerra. CO N SO LIN , M . C. 2002.“ Florecimento e degeneração do 'Espírito das N ações'". In: H istória: Q uestões \& D ebates, Curitiba, n. 37, p. 159182.

CO U ZIN ET, M -D. 1996. H istoire et méthode à la rennaissance - une lecture de la M ethodus de Jean Bodin. Paris:V rin.

LEBRU N , G. 2001. “H ume e a astúcia de Kant”. In.: Sobre K ant. São Paulo: Iluminuras. 
M AQ U IAVEL, N . 1991. II Principe.Torino: Einaudi.

M OU R A, C. A. R . 2001. "H istória Stultitiae e H istória Sapientiae" . In.: $\mathrm{R}$ acionalidade e $\mathrm{C}$ rise - $\mathrm{E}$ studos de $\mathrm{H}$ istória da Filosofia M oderna e C ontemporânea. São Paulo e C uritiba: D iscurso Editorial e Ed. U FPR .

PO LÍBIO. 2003. The H istories. Trad. W. R. PATO N . London: Loeb Classical Library.

PO M EAU, R . 1964. "Présentation”. In.: D iđionaire Philosophique (Voltaire). Paris: Garnier-Flammarion.

. 1990. "Introduction". In.: E ssai sur les moeurs et l'esprit des nations (Voltaire), tomo I. Paris: Garnier.

. 1957. "Preface" . In.: O euvres H istoriques (Voltaire). Paris: Gallimard.

PO RTER , R .;TEICH , M . (O rgs.). 1986. R evolution in H istory. C ambridge: U niversity Press.

RO U SSEAU, J.-J. 1978. D iscurso sobre as diências e as artes. In: C oleção os Pensadores. São Paulo: Editora Abril.

SO U ZA , M . G. 2001. Ilustração e história - o pensamento sobre a história no Iluminismo francês. São Paulo: Discurso Editorial.

VO LTAIR E. 1964. D iđionaire Philosophique. Paris: Garnier-Flammarion. . 1990. E ssai sur les moeurs et l'esprit des nations. T. I et II. Paris: Garnier. Gallimard.

195. 0 euvres H istoriques, Bibliothèque de la Pléiade. Paris: 